НАУКОВИЙ ВІСНИК

Scientific messenger of Lviv National University of
Veterimary Medicicie and Biotechnologies
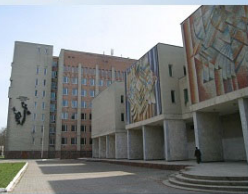

Науковий вісник Аьвівського національного університету ветеринарної медицини та біотехнологій імені С.3. Гжицького. Серія: Ветеринарні науки

Scientific Messenger of Lviv National University of Veterinary Medicine and Biotechnologies. Series: Veterinary sciences doi: 10.32718/nvlvet10417

https://nvlvet.com.ua/index.php/journal

UDC 638.124 .42

\title{
The influence of nanotechnological preparations of plant protection on the viability of bees and the content of microelements in their tissues
}

\author{
I. I. Kovalchuk 1 , R. S. Fedoruk ${ }^{2}$, I. B. Kikish ${ }^{2}$, M. M. Tsap², G. G. Denys ${ }^{2}$ \\ ${ }^{1}$ Stepan Gzhytskyi National University of Veterinary Medicine and Biotechnologies, Lviv, Ukraine \\ ${ }^{2}$ Institute of Animal Biology, NAAS of Ukraine, Lviv, Ukraine
}

Article info

Received 14.10.2021

Received in revised form 15.11 .2021

Accepted 16.11.2021

Stepan Gzhytskyi National

University of Veterinary Medicine

and Biotechnologies Lviv,

Pekarska Str., 50, Lviv,

79010, Ukraine.

Tel.: +38-032-275-65-60

E-mail:pk_vetuniver_lv@ukr.net

Institute of Animal Biology,

Naas of Ukraine

V. Stusa Str., 38, Lviv,

79034, Ukraine.

Tel.: +38-032-260-07-95

E-mail:inenbiol@mail.lviv.ua
Kovalchuk, I. I., Fedoruk, R. S., Kikish, I. B., Tsap, M. M., \& Denys, G. G. (2021). The influence of nanotechnological preparations of plant protection on the viability of bees and the content of microelements in their tissues. Scientific Messenger of Lviv National University of Veterinary Medicine and Biotechnologies. Series: Veterinary sciences, 23(104), $102-109$. doi: $10.32718 /$ nvlvet10417

The research was performed in terms of keeping bees in an incubator. Bees were selected families of analog and divided into control (I) and 6 experimental (II-IV) groups. Over 7 days, bees of control and experimental groups were fed $1 \mathrm{ml}$ sugar syrup (SS), adding to that amount of citrate of polielemental nanotechnology drugs recommended for plant protection - "Avatar-Insecticide" ("A-I") and "AvatarFungicide" ("A-F") in a dilution of 1:1000 (II, III groups) and 1: 500 (IV, V groups) and their VI compatible combination (1:1000) and VII (1:500) groups. Every day number of live and dead bees in groups in absolute and relative values were counted. For 7 th day of feeding bees, drugs were taken to determine Co $\mathrm{Zn}, \mathrm{Cu}, \mathrm{Ag}$ in tissues. The results were statistically processed with the use of Microsoft Excel. The aim of the research is safety for beekeeping use of experimental drugs for plant protection " $A-F$ " and " $A-I$ " the conditions of feeding their bees. The differences of influence of drugs " $A-F$ " and " $A-I$ " on safety and loss of bees, their content in tissues Co and Cu depending on concentration, method, and duration of use were shown. The significant positive effect of feeding " $A-F$ " drug dilution of 1:1000 on the safety of bees with the increase in the number of living by $12.7 \%$ on day 7 compared to the control was noted. Application of this the drug in a dilution of 1:500 and its mixture with " $A$-I" in a dilution of 1:1000 and 1:500 reduced rates of preservation of bees throughout the research period. Separate feeding preparation of " $A-F$ " and " $A-I$ " compatible with dilutions of 1:1000 and 1:500 resulted in the highest content of Co in the tissues of bees. Noted lower Cu content in tissues bee research groups at higher levels amid Zn and Ag by joint action both drugs in a dilution of 1:500 compared to the control. The results indicate a toxic effect of "A-I" drug to bees in the laboratory employed in concentrations and combinations and drug " $A-F$ " - only a dilution of 1:500. Found high the ability of the cumulative drug doses applied " $A-F$ " content of Co tissues of bees.

Key words: bees, mineral elements, entomological cage, citrates, viability.

\section{Вплив нанотехнологічних препаратів захисту рослин на життсздатність бджіл і вміст мікроелементів у їх тканинах}

\author{
I. І. Ковальчук ${ }^{1}$, Р. С. Федорук², І. Б. Кикіш², М. М. Цап², Г. Г. Денис ${ }^{2}$ \\ ${ }^{1}$ Львівський національний університет ветеринарної медицини та біотехнологій імені С. 3. Гжицького, м. Львів, \\ Україна \\ ${ }^{2}$ Інститут біології тварин НААН, м. Львів, Украӥна
}

Дослідження виконані в умовах утримання бджіл в термостаті. Бджоли були відібрані від сімей-аналогів і поділені на контрольну (I) і 6 дослідних (II-VI) груп. Упродовж 7-ми діб досліджень бджслам контрольної та дослідних груп згодовували 1 мл иук- 
рового сиропу (ЦС) з додаванням до иього об'єму иитратів поліелементних нанотехнологічних препаратів, рекомендованих для захисту рослин - “Аватар-Інсектицид” (“А-I”) та “Аватар-Фунгіцид” (“А-Ф”) у розведеннях 1:1000 (II, III групи) та 1:500 (IV, V групи), а також їх сумісного поєднання в VI (1:1000) VII (1:500) групах. Кожної доби підраховували кількість живих $і$ мертвих бджіл по групах в абсолютних і відносних величинах. На 7-му добу згодовування препаратів відбирали бджіл для визначення вмісту $\mathrm{Co}, \mathrm{Zn}, \mathrm{Cu}, \mathrm{Ag}$ у тканинах організму. Результати опрачьовані статистично з використанням комп 'ютерної програми Місголоft Excel. Мета досліджень - визначити безпечність для бджільниитва застосування експериментальних препаратів для захисту рослин “А-I” та “А-Ф” за умов згодовування їх бджолам. Встановлені відмінності впливу препаратів “А-I” та “А-Ф” на збереженість $і$ загибель бджіл, вміст у їхніх тканинах Со та Си залежно від концентрації, способу і тривалості застосування. Відзначено суттєвий позитивний вплив згодовування препарату “А-Ф” у розведенні 1:1000 на збереженість бджіл з підвищенням кількості живих на 12,7 \% на 7-му добу стосовно контролю. Застосування цьього препарату у розведенні 1:500 та його суміші з “А-I” у розведеннях 1:1000 і 1:500 зменшувало показники збереженості бджіл упродовж всього дослідного періоду. Роздільне вигодовування препарату “А-Ф” і сумісне з “А-I” у розведеннях 1:1000 та 1:500 зумовлювало найвищий вміст Со у тканинах бджіл. Відзначено нижчий вміст Си у тканинах бджіл дослідних груп на тлі вищого рівня Zn i Ag за сумісної дї обох препаратів у розведенні 1:500 порівняно з контролем. Отримані результати вказують на токсичну дію препарату “А-I” на медоносних бджіл у застосованих в умовах лабораторії концентраціях та поєднаннях, а препарату “А-Ф”- лите у розведенні 1:500. Встановлено високу кумулятивну здатність препарату “А-Ф” у застосованих дозах щуодо вмісту Со у тканинах організму бджіл.

Ключові слова: бджоли, мінеральні елементи, ентомологічні садки, цитрати, життєздатність.

\section{Вступ}

Мінеральне живлення медоносних бджіл, як і ссавців, забезпечується надходженням у травний тракт життєвоважливих елементів, фізіологічна роль яких встановлена для організму $(\mathrm{Mg}, \mathrm{Ca}, \mathrm{Fe}, \mathrm{Zn}, \mathrm{Co}, \mathrm{Cu}$, $\mathrm{Mn}, \mathrm{I}, \mathrm{Se}) 3$ природного корму - пилку і нектару або паді (Romaniv \& Kovalchuk, 2012; Kovalchuk et al., 2014; 2017; 2020) та води (Matuszewska et al., 2021). Разом 3 тим живлення бджіл у природних умовах 3 інтенсивним техногенним навантаженням на довкілля зумовлює негативний вплив на їхню життєдіяльність (Kovalchuk, 2012; Zhumadina et al., 2015; DeGrandiHoffman et al., 2018; Pashaian et al., 2021). Особливо шкідливими для медоносних бджіл є отрутохімікати дефоліанти, гербіциди, акарициди та інші (MoralesDíaz et al., 2017; Taran et al., 2017; Kopittke et al., 2019), , у т. ч. на тих с.-г. культурах, з яких бджоли збирають пилок і нектар (ріпак, соняшник, гречка). Відомо, що більшість цих отрутохімікатів володіють токсичним впливом на комах і зумовлюють загибель бджолиних сімей (Saranchuk, 2011; Di Prisko et al., 2013; Buchler et al., 2014; Hatjina et al., 2014; Piiroinen \& Goulson, 2016). Зокрема, пестициди з групи нікотиноїдів порушують розвиток і функцію гіпофарингіальних залоз бджіл, що зумовлює зменшення синтезу білка маточного молочка та його секреції у бджіл-годувальниць (Hatjina et al., 2013; Wilde et al., 2016). Показано, що екологічне забруднення довкілля пестицидами нейротоксичної дії може зумовлювати сповільнену та кумулятивну дію на організм бджіл (Rondeau et al., 2014).

У зв'язку з широким використанням отрутохімікатів у с.-г. виробництві в США щорічна загибель бджолиних сімей становить від 30 до $90 \%$. У США в 2019 році кількість бджолиних сімей, що загинули становила $40 \%$. Тому агентство з охорони навколишнього природного середовища (ЕРА) заборонило 12 пестицидів, шкідливих для бджіл. Аналогічні проблеми відзначаються у бджільництві Великої Британії, Німеччини, Греції, Польщі та багатьох інших країнах. Доведено, що надходження токсичних речовин 3 таких отрутохімікатів з пилком, нектаром, водою навіть у незначних кількостях зумовлює послаблення резистентності організму бджіл, сили бджолиної сім'ї та їі загибелі (Senchuk et al., 2020).
В Україні налагоджене виробництво водорозчинного препарату "Мелавіт", що містить меланін і проявляє антидегеративну, антиоксидантну, імунопротекторну та сорбуючу дію в організмі. Встановлено, що згодовування бджолам цукрового сиропу з додаванням рослинного меланіну в кількості 0,1 мкг/л води уповільнює природне відмирання бджіл на 2,8-50,5 \% (Yefimenko et al., 2020). Автори розглядають можливість його застосування у стресових ситуаціях зумовлених отруєнням бджіл пестицидами. Рекомендується випоювати бджолам воду 3 додаванням меланіну у періоди інтенсивного нарощування сім'ї під час оброблення нектароносних угідь пестицидами.

На даний час в Україні налагоджене унікальне альтернативне екологічне виробництво нанотехнологічних карбоксилатів на основі макро-мікроелементів, безпечність для людей i тварин яких підтверджена низкою досліджень у провідних наукових центрах (Serdiuk et al., 2010; Borisevich et al., 2012; Kovalchuk, 2012; Fedoruk et al., 2014; Hulich et al., 2018). Біологічна ефективність вказаних сполук доведена в рослинництві як мікродобрив (Chichiricco \& Poma, 2015; Dykman \& Shchyogolev, 2017; Kapitanska et al., 2017; Read et al., 2019; Stasik et al., 2020) та препаратів захисту рослин (Priadkina et al., 2014; Bityutskyy et al., 2017).

Проведені дослідження вказують на різнобічний вплив цих сполук на фізіолого-біохімічні процеси у рослин (Savchuk \& Starodub, 2017; Savchuk et al., 2018; Sansari et al., 2019; Stasik et al., 2020). Дія цих елементів впливає також на життєдіяльність медоносних бджіл (Fedoruk et al., 2017; Kykish et al., 2017; 2018), ïx медову продуктивність, та репродуктивну функцію організму бджолиних маток (Dvyliuk, 2015; Kykish \& Kovalchuk, 2016; Fedoruk et al., 2016; DeGrandiHoffman et al., 2018; Kovalchuk et al., 2020).

Низка публікацій вказує на можливість використання нанокарбоксилатів хімічних поліелементів “Аватар-Інсектицид” і “Аватар-Фунгіцид” у рослинництві як альтернативних мікродобрив і препаратів захисту с.-г. культур до хімічно синтезованих їх аналогів (Priadkina, 2014; Kapitanska et al., 2016; Vatansever et al., 2017; Savchuk \& Starodub, 2017; Sansari et al., 2019). 
Однак вплив цих препаратів на життєдіяльність медоносних бджіл не досліджено. Тому метою роботи було вивчення токсикологічної дії різних доз поліелементних сумішей нанотехнологічних цитратів у вигляді експериментальних препаратів “АватарІнсектицид” i “Аватар-Фунгіцид” за умов їх згодовування 3 цукровим сиропом медоносним бджолам у лабораторному термостаті.

\section{Матеріал та методи досліджень}

Дослідження виконані на бджолах карпатської породи, отриманих від сімей-аналогів 3 пасіки-віварію Інституту біології тварин НААН, що були поділені на 7 груп і утримувались у садках в умовах лабораторного термостату. I група - контрольна, отримувала щоденно 1 мл 50 \%-го цукрового сиропу (ЦС) + 1 мл дистильованої $\mathrm{H}_{2} \mathrm{O}$; II група - 1 мл ЦС +1 мл препарату “Аватар-Інсектицид” (“А-I”) у розведенні 1:1000; III група - 1 мл ЦС + 1 мл препарату “АватарФунгіцид” (“А-Ф”) у розведенні 1:1000; IV група 1 мл ЦС + 1 мл препарату “А-I” у розведенні 1:500; V група - 1 мл ЦС + 1 мл препарату “А- $\Phi$ ” у розведенні 1:500; VI група - 1 мл ЦС + по 0,5 мл препаратів “А-I” та “А-Ф” у розведенні 1:1000; VII група 1 мл ЦС + по

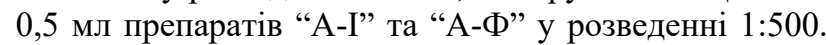
Цитрати поліелементних препаратів “А-I” i “А-Ф” виготовлені нанотехнологічним методом (Kosinov \& Kaplunenko, 2009). Бджоли контрольної та дослідних груп утримувалися в аналогічних умовах ентомологічних садків із розміщенням їх у термостаті з мікровентиляцією за температури 29,0-30,0 ${ }^{\circ} \mathrm{C}$ впродовж 7 ми діб досліджень. У дослідний період проводили підгодівлю бджіл цукровим сиропом і препаратами в ранковий час доби з щоденним їх підрахунком кількості живих і мертвих. Для лабораторних досліджень з кожної групи були відібрані бджоли для визначення вмісту мікроелементів у тканинах організму. Мінералізацію проб проводили методом сухого озолення у муфельній печі при $\mathrm{t}_{\max }=450{ }^{\circ} \mathrm{C}$, одержані зразки золи розводили в 6 н $\mathrm{HCl}$ і визначали вміст окремих мікроелементів ( $\mathrm{Co}, \mathrm{Zn}, \mathrm{Cu}, \mathrm{Ag}$ ) на атомно-абсорбційному спектрофотометрі СФ-115 ПК, абсолютні концентрації вмісту виражали у міліграмах на кілограм натуральної маси (мг/кг) (Vlizlo et al., 2012). Цифрові дані опрацьовані статистично 3 використанням комп'ютерної програми Microsoft EXCEL з визначенням середніх величин M, їх відхилень \pm m i ступеня вірогідності міжгрупових різниць із використанням коефіцієнта Стьюдента (Р).

\section{Результати та їх обговорення}

Аналіз результатів динаміки збереженості та загибелі бджіл за умов підгодівлі препаратами “А-I" та “А-Ф” вказує на слабо виражену токсичну дію обох цих препаратів у першу добу їх випоювання у застосованих розведеннях (табл. 1). Збереженість бджіл у II-VI дослідних групах була меншою порівняно до контрольної групи на 2,86-8,34\%. Однак сумісне застосування вказаних препаратів у розведенні 1:500 в VII групі не зумовлювало загибелі бджіл в цей період.

На 2-гу добу кількість живих бджіл перевищувала контрольну групу за дії “А-I" (+2,33 \%) та “А- $Ф$ " $(+9,92 \%)$ у розведенні $1: 1000$, проте була меншою за сумісного згодовування цих препаратів у VI $(-19,10 \%)$ i VII $(-21,74 \%)$. На 3- і 4-ту доби вища збереженість бджіл встановлена лише для III групи за

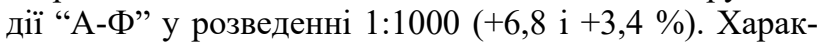
терно, що на 5 і 6 доби кількість живих бджіл у II і III групах переважала контрольну групу на 3,72 \% i 4,62 \% за розведення суміші “А-I” i “А-Ф” 1:1000 при досягненні вищої збереженості бджіл у цих групах на 7 добу. Найвищу збереженість бджіл (34,38\% або $+12,65$ \% до контролю) відзначено за дії “А- $\Phi$ ” у розведенні 1:1000 на 7 добу його застосування. Аналіз середніх величин збереженості бджіл за дослідний період вказує на виражений стимулюючий вплив

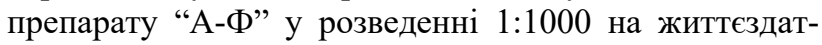
ність бджіл (68,8 \% живих особин), що становить $+3,6$ \% до контрольної групи.

Одержані результати можуть вказувати на незначний стимулюючий вплив препарату “А- $\Phi$ ” у розведенні 1:1000 (III група) за умов 7-добового надходження його в організм бджіл. У той час як препарат “А-I” у розведеннях 1:500 і 1:1000 та його поєднання 3 “А- $\Phi ”$ у цих розведеннях зумовлювали вищу загибель бджіл, що коливалася від 0,9 \% (II група) до 19,5 \% (IV група), 11,0 \% (V група) та 8,1 (VI група) i 13,0 \% (VII група) у їх сумішей порівняно 3 контролем (I група). Очевидно, токсичність досліджених препаратів може бути зумовлена як високими дозами окремих їх компонентів, так і посиленням такого впливу у зв'язку з комплексним їх застосуванням і кумулятивною здатністю окремих макро- і мікроелементів.

Визначення вмісту $\mathrm{Co}, \mathrm{Zn}, \mathrm{Cu}$, i $\mathrm{Ag}$ у тканинах бджіл вказує на відмінності впливу застосованих концентрацій препаратів “А-I” і “А- $\Phi$ ” на рівень цих елементів в їх організмі (табл. 2).

Зокрема, концентрація Со була вірогідно вищою у тканинах бджіл III-VII груп, що свідчить про підвищене надходження в травний канал і засвоєння кобальту із застосованих препаратів у бджіл дослідних груп від контрольної групи. Однак, на вищому рівні ці процеси протікали у бджіл, яким згодовували препарат “А-Ф” (III і V групи). Характерно, що сумісне застосування "А-I" 3 “А-Ф” зберігало вищий вміст $(\mathrm{P}<0,001)$ Со у тканинах бджіл як за більшого розведення (VI група), так і меншого (VII група). Очевидно, застосовані концентрації вказаних препаратів стимулювали кумулятивну здатність Со у тканинах організму бджіл. 
Таблиця 1

Динаміка збереженості та загибелі бджіл за умов термостату

\begin{tabular}{|c|c|c|c|c|c|c|c|c|}
\hline \multirow{3}{*}{ Показник } & \multirow{3}{*}{ Доба } & \multicolumn{7}{|c|}{ Групи бджіл } \\
\hline & & \multirow{2}{*}{$\frac{\text { Контроль }}{\mathrm{I}}$} & \multicolumn{6}{|c|}{ Дослідні } \\
\hline & & & II & III & IV & $\mathrm{V}$ & VI & VII \\
\hline \multirow{2}{*}{ К-сть бджіл, \% } & & 23 & 28 & 32 & 35 & 24 & 28 & 23 \\
\hline & & 100 & 100 & 100 & 100 & 100 & 100 & 100 \\
\hline \% живих & & 100 & 96,42 & 96,87 & 97,14 & 91,66 & 92,85 & 100 \\
\hline \pm до к-лю & 1 & - & $-3,58$ & $-3,13$ & $-2,86$ & $-8,34$ & $-7,15$ & - \\
\hline \% мертвих & & 0 & 3,58 & 3,13 & 2,86 & 8,34 & 7,15 & 0 \\
\hline \% живих & & 86,9 & 89,28 & 96,87 & 54,28 & 87,50 & 67,85 & 65,21 \\
\hline \pm до к-лю & 2 & - & $+2,33$ & $+9,92$ & $-32,67$ & $-0,55$ & $-19,10$ & $-21,74$ \\
\hline \% мертвих & & 13,05 & 10,72 & 3,13 & 45,72 & 12,50 & 32,15 & 34,79 \\
\hline \% живих & & 86,9 & 82,14 & 93,75 & 51,42 & 83,33 & 67,85 & 60,86 \\
\hline \pm до к-лю & 3 & - & $-4,81$ & $+6,80$ & $-35,53$ & $-3,62$ & $-19,10$ & $-26,09$ \\
\hline \% мертвих & & 13,05 & 17,86 & 6,25 & 48,58 & 16,67 & 32,15 & 39,14 \\
\hline \% живих & & 43,5 & 42,85 & 46,87 & 28,57 & 37,50 & 42,85 & 30,43 \\
\hline \pm до к-лю & 4 & - & $-0,62$ & $+3,40$ & $-14,90$ & $-5,97$ & $-0,62$ & $-13,04$ \\
\hline \% мертвих & & 56,53 & 57,15 & 53,13 & 71,43 & 62,50 & 57,15 & 69,57 \\
\hline \% живих & & 39,10 & 42,85 & 37,50 & 14,28 & 25,00 & 35,72 & 26,08 \\
\hline \pm до к-лю & 5 & - & $+3,72$ & $+4,62$ & $-24,85$ & $-14,13$ & $-3,41$ & $-13,05$ \\
\hline \% мертвих & & 60,87 & 57,15 & 56,25 & 85,72 & 75,00 & 64,28 & 73,92 \\
\hline \% живих & & 39,13 & 42,85 & 43,75 & 11,43 & 8,33 & 32,15 & 21,73 \\
\hline 土 до к-лю & 6 & - & $+3,72$ & $+4,62$ & $-27,7$ & $-30,80$ & $-6,98$ & $-17,40$ \\
\hline \% мертвих & & 60,87 & 57,15 & 56,25 & 88,57 & 91,67 & 67,85 & 78,27 \\
\hline \% живих & & 21,70 & 28,58 & 34,38 & 0 & 4,16 & 10,71 & 0 \\
\hline \pm до к-лю & 7 & - & $+6,85$ & $+12,65$ & 0 & $-17,57$ & $-11,02$ & 0 \\
\hline \% мертвих & & 78,27 & 71,42 & 65,62 & 100 & 95,84 & 89,29 & 100 \\
\hline Середнє: & & & & & & & & \\
\hline живих, шт./\% & & $15 / 65,2$ & $18 / 64,3$ & $22 / 68,8$ & $16 / 45,7$ & $13 / 54,2$ & $16 / 57,1$ & $12 / 56,5$ \\
\hline \pm до к-лю & & 8 & 10 & 10 & 19 & 11 & 12 & 10 \\
\hline мертвих, \% & & 34,8 & 35,7 & 31,2 & 54,3 & 45,8 & 42,9 & 43,5 \\
\hline \pm до к-лю & & 0 & $-0,9$ & $+3,6$ & $-19,5$ & $-11,0$ & $-8,1$ & $-13,0$ \\
\hline
\end{tabular}

\section{Таблиця 2}

Вміст мікроелементів у тканинах медоносних бджіл

\begin{tabular}{ccccc}
\hline Група & \multicolumn{4}{c}{ Мікроелемент (мг/кг) } \\
\cline { 2 - 5 } бджіл & Со & $\mathrm{Zn}$ & $\mathrm{Cu}$ & $\mathrm{Ag}$ \\
\hline I & $3,8 \pm 0,38$ & $18,72 \pm 3,7$ & $52,8 \pm 4,1$ & $1,0 \pm 0,20$ \\
II & $2,51 \pm 0,64$ & $13,56 \pm 1,4$ & $11,22 \pm 2,11^{* * *}$ & $0,95 \pm 0,11$ \\
III & $45,2 \pm 3,74^{* * *}$ & $28,21 \pm 3,6$ & $23,3 \pm 5,65^{*}$ & $1,3 \pm 0,18$ \\
IV & $5,6 \pm 0,34^{*}$ & $19,74 \pm 1,9$ & $21,8 \pm 2,67^{* *}$ & $1,0 \pm 0,12$ \\
V & $52,9 \pm 5,82^{* * *}$ & $37,68 \pm 3,5^{*}$ & $49,1 \pm 4,39$ & $1,3 \pm 0,15$ \\
VI & $33,6 \pm 0,42^{* * *}$ & $26,18 \pm 4,3$ & $28,8 \pm 2,85^{* *}$ & $1,2 \pm 0,04$ \\
VII & $43,2 \pm 2,74^{* * *}$ & $37,87 \pm 2,0^{* *}$ & $41,6 \pm 2,82$ & $1,6 \pm 0,09^{*}$ \\
\hline
\end{tabular}

Примітка: вірогідні різниці вмісту окремих мікроелементів у тканинах організму бджіл II, III, IV, V, VI та VII дослідних груп порівняно до І контрольної групи; * - $\mathrm{P}<0,05 ; * *-\mathrm{P}<0,01 ; * * *-\mathrm{P}<0,001$

Важлива роль цинку в організмі бджіл визначає його потребу в кормах для функціонування окремих систем та органів (Kovalchuk et al., 2020). Однак відсутність вірогідних різниць вмісту цього елемента у тканинах бджіл II-VI груп порівняно до контролю може вказувати на достатній рівень його забезпечення в організмі з природнього корму до початку експерименту. Разом з тим, суттєве підвищення вмісту цинку

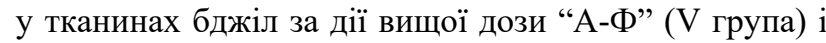
його поєднання в цій дозі з “А-I” (VII група, P < 0,01) вказує на посилення засвоєння і нагромадження Zn в їх організмі за дії препарату “А- $\Phi$ ”.

Аналіз вмісту $\mathrm{Cu}$ в організмі бджіл вказує на протилежну залежність впливу різних доз “А-I" і “А-Ф” на кумуляцію цього елемента в організмі. Зокрема, застосування цих препаратів зумовлювало вірогідне зниження вмісту міді у тканинах бджіл II-IV i VI груп порівняно з контрольною зі збереженням цієї тенденції у бджіл V i VII груп. Очевидно, елементний склад застосованих препаратів зумовлював інгібуючий вплив на засвоєння $\mathrm{Cu} 3$ корму та кумуляцію у тканинах бджіл дослідних груп. Встановлені коливання можуть свідчити про міжгрупові різниці надходження $\mathrm{Cu} 3$ трофічного ланцюга, нагромадження iіï в окремих тканинах організму, оскільки цей елемент бере участь в різноманітних процесах метаболізму. Відомо, що від рівня $\mathrm{Cu}$ в організмі медоносних бджіл залежить інтенсивність синтезу амінокислот, а значна ii кількість виділяється з особливим секретом заглоткових залоз молодих робочих бджіл - маточним молочком 
(Lebedev, \& Bylash, 1991; Taranov, 2020). Основна кількість $\mathrm{Cu}$ в організмі бджіл міститься в кутикулі зовнішньому скелеті, який покриває тіло бджоли і хітинових утвореннях, що формують внутрішній скелет (Taranov, 2020).

Концентрація Ag у тканинах бджіл дослідних груп вірогідно не відрізнялася від контролю. Однак дія “А$\Phi ”$ відзначалася вираженою тенденцією до вищого його вмісту у тканинах бджіл III і V груп з вірогідним зростанням у VII групі, що вказує на фізіологічну відмінність дії препарату “А-Ф” на рівень $\mathrm{Ag}$ в організмі бджіл.

Отже, отримані результати вказують на посилення нагромадження Со - за дії “А- $Ф$ ” в концентрації 1:1000 (III група) і 1:500 (V група) та його поєднання 3 “А-I” у цих же розведеннях (VI і VII групи), а також менше виражене за дії “А-I” в розведенні 1:500 (IV група) та Zn у тканинах бджіл за комплексного застосування “А-I” + “А- $\Phi ”$ у розведенні 1:500 що необхідно враховувати у період застосування цих препаратів для захисту рослин від шкідників та хвороб.

\section{Висновки}

1. Додавання до цукрового сиропу підгодівлі бджіл експериментальних макро-мікроелементних препаратів для захисту рослин “Аватар-Інсектицид” і “Аватар-Фунгіцид” у різних дозах, отриманих методами нанотехнології, зумовлює не однаковий вплив на життєздатність їхнього організму та вміст у тканинах $\mathrm{Co}, \mathrm{Zn}, \mathrm{Cu}, \mathrm{Ag}$. Біологічна дія препаратів залежить від концентрації препаратів, їх елементного складу та тривалості згодовування.

2. Дія препарату “Аватар-Фунгіцид” у розведенні 1:1000 зумовлювала підвищення життєздатності бджіл i вмісту Сo у тканинах організму i характеризувалася вищими показниками збереженості бджіл впродовж періоду згодовування та коригуванням рівнів $\mathrm{Co}$ i $\mathrm{Cu}$ у тканинах.

3. Роздільне і сумісне застосування у підгодівлі бджіл нанотехнологічних препаратів захисту рослин від хвороб і шкідників “Аватар-Фунгіцид” і “АватарІнсектицид” стимулювало підвищення вмісту Со у тканинах організму III, V і VII груп на тлі зниження $\mathrm{Cu}$ у всіх дослідних групах порівняно з контрольною. Вміст Zn i Ag у тканинах вірогідно зростав лише за поєднаної дії суміші обох препаратів у розведенні 1:500, що вказує на можливий їх кумулятивний вплив у застосованій концентрації.

Перспективи подальших досліджень. Одержані результати дають підстави для проведення додаткових досліджень токсичності нанотехнологічних поліелементних препаратів “Аватар-Інсектицид” та “Аватар-фунгіцид” у менших дозах за різної тривалості застосування.

Відомості про конфлікт інтересів. Автори стверджують про відсутність конфлікту інтересів щодо їх вкладу та результатів досліджень.

\section{References}

Bityutskyy, V., Tsekhmistrenko, O., Tsekhmistrenko, S., Spivak, M., \& Shadura, Yu. (2017). Perspektyvy vykorystannia nanochastynok tseriiu u silskomu hospodarstvi [Perspectives of cerium nanoparticles use in agriculture]. Biolohiia Tvaryn, 19(3), 9-17. doi: 10.15407/animbiol19.03.009 (in Ukrainian).

Borisevich, V. B., Kaplunenko, V. G., Kosinov, N. V., et al. (2012). Nanomaterialy ta nanotekhnolohii $u$ veterynarnii praktytsi [Nanomaterials and nanotechnologies in veterinary practice]. K.: WA "Avicenna" (in Ukrainian).

Buchler, R., Costa, C., Hatjina, F., Andonov, S., Meixner, M., Conte, Y., \& Wilde, J. (2014). The influence of genetic ori-gin and its interaction with environmental effects on the sur-vival of Apis mellifera L. colonies in Europe. Journal of Apicultural Research, 53, 205214. doi: 10.3896/IBRA.1.53.2.03.

Chichiricco, G., \& Poma, A. (2015). Penetration and toxicity of nanomaterials in higher plants. Nanomaterials, 5(2), 851-873. doi: 10.3390/nano5020851.

DeGrandi-Hoffman, G., Gage, S. L., Corby-Harris, V., Carroll, M., Chambers, M., \& Graham, H. (2018). Connecting the nutrient composition of seasonal pollens with changing nutritional needs of honey bee (Apis mellifera L.) colonies. Journal of Insect Physiology, 109, 114-124. doi: 10.1016/j.jinsphys.2018.07.002.

Di Prisco, G., Cavaliere, V., Annoscia, D., Varricchio, P., Caprio, E., Nazzi, F., ... \& Pennacchio, F. (2013). Neonicoti-noid clothianidin adversely affects insect immunity and pro-motes replication of a viral pathogen in honey bees. Proceedings of the National Academy of Sciences, 110(46), 18466-18471. doi: 10.1073/pnas.1314923110.

Dvyliuk, I. I. (2015). Vmist zahalnykh lipidiv i spivvidnoshennia yikh klasiv u tkanynakh medonosnykh bdzhil za umov zghodovuvannia tsytrativ $\mathrm{Ag}$ i $\mathrm{Cu}$ [The content of total lipids and the ratio of their classes in the tissues of honey bees under the conditions of feeding citrate $\mathrm{Ag}$ and $\mathrm{Cu}$ ]. Biolohiia Tvaryn, 17(4), 169 (in Ukrainian).

Dykman, L. A., \& Shchyogolev, S. Y. (2017). Interactions of plants with noble metal nanoparticles (review). Agricurtural biology, 52(1), 13-24. doi: 10.15389/agrobiology.2017.1.13eng.

Fedoruk, R. S., Kovalchuk, I. I., Pashhenko, A. G., Romaniv, L. I. \& Kykish, I. B. (2017). Tsytratnyi kompleks mikroelementiv "Avatar" stymuliuie rezystentnist i vyzhyvannia bdzhil [Citrate complex of trace elements "Avatar" stimulates the resistance and survival of bees]. Ahrarnyi tyzhden, 11, 71-73 (in Ukrainian).

Fedoruk, R. S., Kovalchuk, I. I., Romaniv, L. I., \& Khrabko, M. I. (2014). Vplyv tsytrativ hermaniiu ta selenu na vmist lipidiv i vazhkykh metaliv $\mathrm{v}$ orhanizmi medonosnykh bdzhil [Influence of germanium and selenium citrates on the content of lipids and heavy metals in the body of honey bees]. Biolohiia Tvaryn, 16(2), 141-149 (in Ukrainian). 
Fedoruk, R. S., Pashhenko, A. G., Kovalchuk, I. I., \& Romaniv, L. I. (2016). Intensivnost' otkladyvanija jaic pchelinymi matkami $\mathrm{V}$ vesennij period pri skarmlivanii ih sem'jam citratov Co i Ni s saharnym siropom [Intensity of laying eggs by queen bees in spring when feeding $\mathrm{Co}$ and $\mathrm{Ni}$ citrates with sugar syrup to their families]. Sollection of works of scientific symposium with international participation "Zootechnycal science - an important factor for the european type of the agriculture". Maximovca, 774 779 (in Russian).

Hatjina, F., Costa, C., Buchler, R., Uzunov, A., Drazic, M., Filipi, J., \& Kezic, N. (2014). Population dynamics of European honey bee genotypes under different environmental condi-tions. Journal of Apicultural Research, 53, 233-247. doi: 10.3896/IBRA.1.53.2.05.

Hulich, M. P., Yemchenko, N. L., Kharchenko, O. O., Yashchenko, O. V., Tomashevska, L. A., \& Antomonov M. Iu. (2018). Produkty nanotekhnolohii: tsytraty bioelementiv (khimichna kharakterystyka, biolohichna diia, sfera zastosuvannia) [Nanotechnology products: citrates of bioelements (chemical characteristics, biological action, scope)]. Kyiv: MVTs "Medinform" (in Ukrainian).

Kapitanska, O. S., Priadkina, G. A., \& Stasik, O. O. (2017). Vplyv obrobky roslyn kompleksom karboksylativ mikroelementiv na fotosyntetychni pokaznyky i vrozhai ozymoi pshenytsii [Influence of treatment of plants with a complex of carboxylates of microelements on photosynthetic indicators and harvest of winter wheat.]. Fiziolohiia roslyn i henetyka, 49(3), 248-255 (in Ukrainian).

Kapitanska, O. S., Priadkina, G. O., Stasik, O. O., \& Huralchuk Zh. Z. (2016). Zviazok mizh parametramy aktyvnosti fotosyntetychnoho aparatu ta vrozhainistiu ozymoi pshenytsi pry obrobtsi khelatnymy mikrodobryvamy [Relationship between parameters of photosynthetic appa- ratus activity and yield of winter wheat under chelated microfertilizers treatment]. Fiziolohiia roslyn i henetyka, 48(6), 530-537. doi: 10.15407/frg2016.06.530 (in Ukrainian).

Kaplunenko, V. H., Fedoruk, R. S., Kovalchuk, I. I., Pashchenko, A. H., Romaniv, L. I., Dvyliuk, I. I., \& Kykish, I. B. (2017). Biologic action of citrates of the microelements in melliferous bees in different periods of their lives. Journal of Trace Elements in Medicine and Biology, 41(S1), 64.

Kopittke, P. M., Lombi, E., Wang, P. Schjoerring, J. K., \& Husted, S. (2019). Nanomaterials as fertilizers for improving plant mineral nutrition and environmental outcomes. Environmental Science Nano, 6(12), 3513 3524. doi: 10.1039/C9EN00971J.

Kosinov, M. V., \& Kaplunenko, V.G. (2009). Pat. 38391 UA, IPC: C07C 51/41, C07F 5/00, C07F 15/00, C07C 53/126, C07C 53/10, A23L 1/00, B82B 3/00. Sposib otrymannia karboksylativ metaliv. Nanotekhnolohiia otrymannia karboksylativ metaliv [The method of obtaining metal carboxylates. Nanotechnology for the production of metal carboxylates], Publ. 12.01.2009, Biul. № 1 (in Ukrainian).
Kovalchuk, I. I. (2012). Vmist vazhkykh metaliv u tkanynakh medonosnykh bdzhil za umov ekolohichnoho ta orhanichnoho vyrobnytstva. [The content of heavy metals in the tissues of honey bees under conditions of ecological and organic production].Biolohiia tvaryn, 14(1-2), 311-315 (in Ukrainian).

Kovalchuk, I. I. (2013). Vmist Cd, Pb, i Ni v orhanizmi medonosnykh bdzhil za zghodovuvannia tsytratu Khromu ta Selenu [The content of $\mathrm{CD}, \mathrm{Pb}$, and $\mathrm{Ni}$ in the body of honey bees for feeding chromium and selenium citrate]. Veterynarna biotekhnolohiia, 22, 219-223 (in Ukrainian).

Kovalchuk, I. I., \& Kykish, I. B., \& Romaniv, L. I. (2017). Umist okremykh mikroelementiv u tkanynakh medonosnykh bdzhil za zghodovuvannia tsukrovoho syropu i tsytratnoho mikroelementnoho kompleksu "Avatar-Zakhyst" [Content of certain microelements in the tissues of honey bees during feeding of sugar syrup and citrate microelement complex "AvatarProtection"]. NTB DNDKI vetpreparativ ta kormovykh dobavok i Instytutu biolohii tvaryn, 18(2), 89-94 (in Ukrainian).

Kovalchuk, I. I., Fedoruk, R. S., \& Kovalska, L. M. (2014). Vplyv tsytrativ hermaniiu ta selenu na vmist vazhkykh metaliv $\mathrm{v}$ produktsii bdzhilnytstva [Influence of germanium and selenium citrates on the content of heavy metals in beekeeping products]. Naukovyi visnyk Lvivskoho natsionalnoho universytetu veterynarnoi medytsyny ta biotekhnolohii imeni S.Z. Hzhytskoho, 16(2(59), 146-151 (in Ukrainian).

Kovalchuk, I. I., Kykish, I. B., \& Kaplunenko, V. H. (2020). Vplyv tsytrativ mikroelementiv na reproduktyvnu zdatnist bdzholynykh matok [Actual problems of natural sciences: modern scientific discussions]: Collective monograph. Riga, Latvia : "Baltija Publishing", 87-110. doi: 10.30525/9789934-26-025-4-6 (in Ukrainian).

Kykish, I. B., \& Kovalchuk, I. I. (2016). Toksichnost' raznyh doz citratov So i Ge v sostave saharnogo siropa dlja medonosnyh pchel [Toxicity of different doses of citrates $\mathrm{Co}$ and Zhe in the composition of sugar syrup for honey bees]. Collection of works of scientific symposium with international participation "Zootechnycal science - an important factor for the european type of the agriculture", Moldova, Maximovca, 697-702 (in Russian).

Kykish, I. B., Kovalchuk, I. I., \& Romaniv L. I. (2017). Vlijanie raznyh doz mikrojelementnogo preparata na vyzhivaemost' medonosnyh pchel [Influence of different doses of a microelement preparation on the survival of honey bees]. Sovremennye problemy veterinarnoj patologii i biotehnologii $\mathrm{V}$ agropromyshlennom komplekse: materialy Mezhdunarodnoj nauchno-prakticheskoj konferencii, posvjashhennoj 95-letiju RUP "Institut jeksperemintal'noj veterinarii imeni $S . N$. Vyshelesskogo", Minsk, 321-324 (in Russian).

Kykish, I. B., Kovalchuk, I. I., \& Romaniv L. I. (2018). Vplyv mikroelementnogo kompleksu "mikrostymu- 
lin” na zhyttjedijal'nist' bdzhil [Influence of microelement complex "microstimulin" on the activity of bees]. Materialy mizhnarodnoi' naukovopraktychnoi' konferencii' "Aktual'ni problemy fiziologii' tvaryn", prysvjachenoi' 120-richchju Nacional'nogo universytetu bioresursiv i pryrodokorystuvannja Ukrai'ny, m. Chernigiv, 48-49 (in Ukrainian).

Lebedev, V. Y., \& Bylash, N. G. (1991). Byologyja medonosnoj pchely. M.: Agropromyzdat (in Russian).

Matuszewska, E., Klupczynska, A., Maciotek, K. Kokot, Z. I., \& Matysiak J. (2021). Multielemental Analysis of Bee Pollen, Propolis, and Royal Jelly Collected in West-Central Poland. Molecules, 26(9), 2415. doi: 10.3390/molecules26092415.

Morales-Díaz, A., Ortega-Ortíz, H., Juárez-Maldonado, A., Cadenas-Pliego, G., González-Morales, S., \& Benavides-Mendoza, A. (2017). Application of nanoelements in plant nutrition and its impact in ecosystems. Advances in Natural Sciences: Nanoscience and Nanotechnology, 8(1), 1-13. doi: 10.1088/2043-6254/8/1/013001.

Pashajan, S. A., Sidorova, K. A., \& Jurina, T. A. (2021). Nekotorye voprosy povyshenija zhiznestojkosti pchel $\mathrm{v}$ uslovijah tehnogeneza [Optimization of viability indicators of bees under technogenesis conditions]. Vestnik Krasnojarskogo gosudarstvennogo agrarnogo universiteta, 3, 88-92. doi: 10.367181819/4036-20213-88-92 (in Russian).

Piiroinen, S., \& Goulson, D. (2016). Chronic neonicotinoid pesticide exposure and parasite stress differentially affects learning in honey bees and bumble bees. Proceeding of the Royal Society B, 283(1828), doi: 10.1098/rspb.2016.0246.

Priadkina, G. A., Kaplunenko, V. G., Stasik, O. O., \& Kapitanskaia, O. S., (2014). Vlijanie vnekornevoj obrabotki kompleksom mikrojelementov "AVATAR 1" na urozhajnost' vinograda [Effect of foliar treatment by "AVATAR 1" trace element complex on the yield of grapes]. Trace elements in medicine. 15(2), 40-47 (in Russian).

Priadkina, H. O. (2020). Influence of trace elements, applied in classic and nano forms, on photosynthesis of higher plants in relation to enhancement of crop productivity. Agricultural Science and Practice, 7(3), 71-85. doi: 10.15407/agrisp7.03.071.

Read, T. L., Doolette, C. L., Cresswell, T., Howell, N. R., Aughertson, R., Karatchevtseva, I., Donner, E., Kopittke, P. M., Schjoerring, J. K., \& Lombi, E. (2019). Investigating the foliar uptake of $\mathrm{Zn}$ from conventional and nano- formulations: A methodological study. Environmental Chemistry. 16, 459-469. doi: 10.1071/EN19019.

Romaniv, L. I., \& Kovalchuk, I. I. (2012). Alimentarnoproteinovyi chynnyk u zhyttiediialnosti medonosnykh bdzhil [Alimentary-protein factor in the life of honey bees]. Naukovo-tekhnichnyi biuleten Instytutu biolohii tvaryn NAAN, 13(1-2), 125-130 (in Ukrainian).

Rondeau, G., Sa'nchez-Bayo, F., Tennekes, A. H., Decourtye, A., Ramirez-Romero, R., \& Desneux, N.
(2014). Delayed and time-cumulative toxicity of imidacloprid in bees, ants and termites. Scientific Reports, 4, 5566. doi: 10.1038/srep05566.

Sanzari, I., Leone, A., \& Ambrosone, A. (2019). Nanotecnology in plant science: To make a long story short. Front Bioeng Biotechnol, 7(120), 1-12. doi: 10.3389/fbioe.2019.00120.

Saranchuk, I. I. (2011). Vplyv tekhnohenno navantazhenoho dovkillia na zhyrnokyslotnyi sklad i vmist vazhkykh metaliv $u$ tkanynakh bdzhil i bdzholynii produktsii [Influence of technogenic loaded environment on fatty acid composition and content of heavy metals in tissues of bees and bee products]. NTB Instytutu biolohii tvaryn i Derzhavnoho naukovo-doslidnoho kontrolnoho instytutu vetpreparativ ta kormovykh dobavok, 12(3, 4), 43-51 (in Ukrainian).

Savchuk, M. V., \& Starodub, M. F. (2017). Vyznachennja cytotoksychnosti novosyntezovanyh nanokompozytiv na osnovi saponitiv [Determination of the cytotoxicity of new nanocomposites based on saponite]. Naukovyi visnyk NLTU Ukrainy, 27(4), 137-139. doi: 10.15421/40270430 (in Ukrainian).

Savchuk, M., Starodub, M., Bisio, C., Guidotti, M., \& Lisovyy, M. (2018). Estimation of the effi ciency of applying nanocomposites as environmentally safe nanofertilizers to stimulate biometric indices of agricultural crops. Agricultural Science and Practice, $5,64-762$.

Senchuk, T. Y., Hrechka, H. M., \& Rak, T. M. (2020). Mozhlyvosti ta perspektyvy orhanichnoho bdzhilnytstva v Ukraini [Opportunities and prospects for the organic beekeeping in Ukraine]. Bdzhilnytstvo Ukrainy, 4, 57-61 (in Ukrainian).

Serdiuk, A. M., Hulich, M. P., Kaplunenko, V. H., \& Kosinov, M. V. (2010). Nanotekhnolohii mikronutriientiv: problemy, perspektyvy ta shliakhy likvidatsii defitsytu makro- ta mikroelementiv [Nanotechnologies of micronutrients: the problem, perspective and ways to eliminate the deficiency of macro- and microelement]. Visnyk akademii medychnykh nauk, 1, 107-114 (in Ukrainian).

Stasik, O. O., Pryadkina, G. O., Kiriziy, D. A., Sytnyk, S. K., Kapitanska, O. S., MiKhno, A. I., \& Makharynska, N. M. (2020). Vplyv pozakorenevoi obrobky roslyn pshenytsi ozymoi kompleksom mikroelementiv, otrymanym za dopomohoiu nanotekhnolohii, na yikh fotosyntetychnu aktyvnist za riznykh umov volohozabezpechennia [Effect of foliar treatment with microelement complex, obtained by nanotechnology, on the photosynthetic activity of winter wheat plants under different moisture]. Fiziolohiia roslyn i henetyka, 52(1), 46-63. doi: 10.15407/frg2020.01.046 (in Ukrainian).

Taran, N., Storozhenko, V., Svietlova, N., Batsmanova, L., Shvartau, V., \& Kovalenko, M. (2017) Effect of zinc and copper nanoparticles on drought resistance of wheat seedlings. Res Lett, 12(1), 60. doi: 10.1186/s11671-017-1839-9. 
Taranov, G. F. (2020). Anatomija i fiziologija medonosnyh pchel [Anatomy and physiology of honey bees]. K.: Knigonosha (in Ukrainian).

Vatansever, R., Ozyigit, I. I., \& Filiz, E. (2017). Essential and Beneficial Trace Elements in Plants, and Their Transport in Roots: a Review. Appl. Biochem. Biotechnol, 181, 464 482. doi: 10.1007/s12010-016-2224-3.

Vlizlo, V. V., Fedoruk, R. S., \& Ratych, I. B. (2012). Laboratorni metody doslidzhen' u biologii', tvarynnyctvi ta veterynarnij medycyni [Laboratory methods of investigation in biology, stock-breeding and veterinary]. Spolom, Lviv (in Ukrainian).

Wilde, J., Fraczek, R. J., Siuda, M., Bak, B., Hatjina, F., \& Miszczak A. (2016). The influence of sublethal doses of imidacloprid on protein content and proteolytic activity in honey bees (Apis mellifera L.) Journal of Apicultural Research, 55(2), 212-220. doi: 10.1080/00218839.2016.1211394.

Yefimenko, T. M., Odnosum, H. V., Mishchenko, A. I., Vorobiy, O. A., Kovalenko, I. A., \& Tlusta, Y. P. (2020). Vplyv zghodovuvannia melaninu na pryrodne vidmyrannia bdzhil [The effect of melanin feeding on the natural bee's extinction]. Bdzhilnytstvo Ukrainy, 5, 15-18 (in Ukrainian).

Zhumadina, Sh. M., Kalashnikova, M. V., Sidorova, K. A., \& Pashajan, S. A. (2015). Osobennosti morfofunkcional'noj izmenchivosti pchel [Features of morphofunctional variability of bees]. Pavlodar, Kereku (in Russian). 